INFO ARTIKEL

Riwayat Artikel:

Diterima : 08 Juni 2018

Disetujui : 12 Agustus 2018

\title{
PENDIDIKAN
}

\section{PENGARUH MODEL PEMBELAJARAN PROBLEM BASED LEARNING TERHADAP KEMAMPUAN BERPIKIR ANALITIS SISWA SMA NEGERI 2 BANYUASIN 1}

\author{
Eva Yulianti, Meilia Rosani, Nuranisa \\ Pendidikan Geografi Universitas PGRI Palembang \\ (凹) nuranisa.1203854@yahoo.com
}

\begin{abstract}
ABSTRAK
Model pembelajaran merupakan suatu model yang akan diterapkan kepada siswa dalam suatu pembelajaran yang sedang berlangsung dan guna untuk mencapai tujuan pendidikan. Salah satu model pembelajaran yang sesuai untuk meningkatkan kemampuan berpikir analitis siswa yaitu dengan model pembelajaran Problem Based Learning. Penelitian bertujuan untuk mengetahui kemampuan berpikir analitis setelah diterapkan dengan model pembelajaraan Problem Based Learning di kelas XI IPS 1 SMA Negeri 2 banyuasin 1 tahun ajaran 2018/2019. Variabel penelitian ini adalah kemampuan berpikir analitis pada mata pelajaran geografi siswa yang menggunakan model pembelajaran Problem Based Learning pada kelas eksperimen dan juga kemampuan berpikir analitis geografi siswa yang menggunakan pembelajaran konvensional/langsung. Metode yang digunakan adalah metode eksperimen. Pengumpulan data dilakukan dengan tes. Dari hasil penelitian dapat disimpulkan, kemampuan berpikir analitis siswa setelah menggunakan model pembelajaran Problem Based Learning pada kelas eksperimen dengan rata-rata 75,6, sedangkan pada kelas kontrol dengan pembelajaran konvensional/langsung memiliki rata-rata 61,36. Maka dapat ditarik suatu kesimpulan bahwa: ada pengaruh dalam penerapan model pembelajaran Problem Based Learning terhadap kemampuan berpikir analitis siswa SMA Negeri 2 Banyuasin 1 tahun ajaran 2018/2019.
\end{abstract}

Kata kunci: Model Pembelajaran Problem Based Learning, Kemampuan Berpikir Analitis Siswa.

\section{PENDAHULUAN}

Pembelajaran merupakan suatu proses belajar dimana bertujuan untuk mencapai proses yang baik dan pembelajaran memiliki keterkaitan sangat erat dengan proses pendidikan dan hasil pendidikan yang lebih baik. Tanpa adanya proses pembelajaran tentunya proses pendidikan tidak akan memiliki kualitas. Karena pada dasarnya pembelajaran suatu proses penambahan informasi dan kemampuan baru dimana sebuah proses itu berupa cara-cara persiapan suatu kondisi agar terjadinya proses belajar antara guru dan siswa berjalan dengan baik serta tersusun sehingga dapat mencapai tujuan pembelajaran. Untuk itu, perlu diperhatikan proses pembelajaran siswa agar mendapatkan pengetahuan dari kegiatan belajar.

Pembelajaran atau proses belajar mengajar adalah proses yang diatur dengan langkah-langkah tertentu, agar pelaksanaannya mencapai hasil yang diharapkan. Langkah-langkah tersebut biasanya dituangkan dalam bentuk perencanaan mengajar (Majid, 2009:103). Hal tersebut juga selaras dengan beberapa pendapat bahwa pembelajaran adalah suatu kombinasi yang tersusun meliputi unsurunsur manusiawi, material, fasilitas, perlengkapan dan prosedur perlengkapan yang saling 
mempengaruhi mencapai tujuan pembelajaran (Daryanto dan Tasrial, 2012:154).

Tujuan pembelajaran merupakan suatu proses pencapaian pembelajaran dalam perubahan yang terjadi pada siswa setelah mengikuti kegiatan pembelajaran. Tujuan pembelajaran merupakan pernyataan tentang hasil pembelajaran yang diharapkan (Made Wena, 2009:5). Adanya pembelajaran yang lebih terarah dan memiliki langkah-langkah yang lebih efektif dan efisien untuk menjadikan tujuan dari proses pendidikan tercapai dengan baik. Dalam kegiatan pembelajaran, siswa adalah sebagai subjek dan sebagai objek serta kegiatan pengajaran. Oleh karena itu, proses belajar jika siswa dapat berusaha secara aktif tentu akan dapat mencapai tujuan pembelajaran sehingga pengembangan serta perbaikan sistem pembelajaran merupakan upaya yang dianggap tepat dan mampu meningkatkan pembelajaran, untuk itu perbaikan pengajaran harus memperhatikan pengembangan dimana siswa memiliki kesempatan untuk mengembangkan informasi, mengemukakan gagasan atau ide maupun berpendapat dengan mengembangkan kemampuan berpikir.

Upaya mencapai tujuan pembelajaran yang diharapkan, maka dalam pelaksanaan pembelajaran guru diharapkan menggunakan model pembelajaran yang tepat. Penggunaan model dalam kegiatan pembelajaran sangat perlu karena untuk mempermudah proses pembelajaran sehingga dapat mencapai hasil yang optimal. Tanpa model yang jelas, proses pembelajaran tidak akan terarah sehingga tujuan pembelajaran yang telah ditetapkan sulit tercapai secara optimal. Dengan kata lain tidak dapat berlangsung secara efektif dan efisien. Pendekatan PBM berkaitan dengan penggunaan kecerdasan dari dalam diri seseorang dalam sebuah kelompok atau lingkungan untuk memecahkan suatu masalah yang bermakna, relevan, dan faktual.

Kegiatan belajar di sekolah hendaknya berlangsung atas kemampuan, minat, keperluan, dan kebutuhan siswa. Tujuannya adalah untuk mengembangkan keterampilan belajar, keterampilan belajar bebas, mandiri dan kemampuan memecahkan masalah. Guru dalam setiap pembelajaran hendaknya memberikan motivasi dan menggunakan pendekatan, strategi, model, dan metode pembelajaran yang dapat memudahkan siswa memahami materi yang diajarkan. Pemilihan suatu model perlu, karena dalam penggunaan model pembelajaran yang tepat dapat mendorong tumbuhnya rasa senang siswa terhadap pelajaran, menumbuhkan dan meningkatkan motivasi dalam mengerjakan tugas, memberikan kemudahan bagi siswa untuk memahami materi pembelajaran dengan demikian dapat berpengaruh terhadap nilai atau hasil belajar mereka menjadi meningkat dan lebih baik.

Model pembelajaran adalah suatu perencanaan atau pola yang digunakan sebagai pedoman dalam merencanakan pembelajaran. Setiap model pembelajaran mengarah kepada desain pembelajaran untuk membantu siswa sedemikian rupa sehingga tujuan pembelajaran tercapai dengan efektif dan efisien (Suyadi, 2015:14). Jadi adanya pemilihan dan pemberian suatu model pembelajaran akan menjadikan proses belajar siswa lebih mudah dan meningkatkan aktivitas siswa dalam belajar.

Model pembelajaran Problem Based Learning (berbasis masalah) merupakan model pembelajaran yang efektif diterapkan dalam pembelajaran karena siswa secara aktif memaksimalkan kemampuan berpikirnya melalui kegiatan kerja kelompok atau tim yang sistematis, sehingga siswa dapat memberdayakan, mengasuh, menguji, dan mengembangkan kemampuan berpikirnya secara berkesinambungan. Peningkatan kemampuan berpikir analitis berdasarkan Problem Based Learning yang menekankan kepada guru untuk menyajikan bahan pelajaran kepada siswa dalam bentuk jadi, rapi, sistematis dan lengkap sedangkan siswa berkewajiban untuk menguasainya (Rusman, 2012:229). Model pembelajaran Problem Based Learning mudah dikembangkan karena tipe ini sederhana untuk diterapkan dengan tipe-tipe lain. Diharapkan melalui model ini dapat memberikan kesempatan kepada siswa untuk belajar langsung dengan bebas menggunakan modalitas yang demikiannya untuk mencapai pemahaman dan pembelajaran yang efektif.

Dimana dalam proses pembelajaran yang cenderung pasif, siswa kurang berani bertanya dalam mengemukakan pendapat, akibatnya hasil kurang maksimal. Hal tersebut menyebabkan nilai 
mereka masih jatuh yaitu masih banyak mendapat nilai 60 sehingga masih di bawah kriteria ketuntasan minimal (KKM) yaitu 70 pada mata pelajaran geografi. Kesulitan dalam mempelajari materi dikarenakan konsep belajar yang monoton dan kurang bermakna, sehingga minimnya minat dan kemampuan siswa dalam memahami materi. Salah satu upaya yang dapat dilakukan dengan melihat permasalahan tersebut, perlu adanya model yang dapat membuat siswa belajar dengan aktif dan ikut terlibat adanya model yang dapat membuat siswa belajar dengan aktif terlibat langsung dalam proses pembelajaran. Salah satu model pembelajaran yang tepat yaitu model pembelajaran Problem Based Learning. Penggunaan model pembelajaran ini diharapkan dapat membuat siswa termotivasi untuk meningkatkan kemampuan menganalisis serta tercapainya interaksi antara guru dan siswa.

Peneliti memilih model pembelajaran Problem Based Learning karena menuntun siswa belajar dengan efektif, selain itu mampu melatih dan mengembangkan potensi siswa yang telah dimiliki oleh pribadi masing-masing, mampu melibatkan secara maksimal dalam menemukan dan memahami suatu konsep melalui fisik, dan mampu menjangkau setiap gaya pembelajaran siswa. Selain itu model pembelajaran Problem Based Learning mudah dikembangkan karena tipe ini sederhana untuk diterapkan dengan tipe-tipe lain. Dan berdasarkan wawancara dengan guru mata pelajaran bahwa nilai siswa masih dibawah KKM sehingga perlu model pembelajaran baru karena model konvensional sudah tidak bisa digunakan kembali. Berdasarkan uraian diatas, peneliti perlu melakukan penelitian dengan judul "Pengaruh Model Pembelajaran Problem Based Learning Terhadap Kemampuan Berpikir Analitis Siswa SMA Negeri 2 Banyuasin 1".

\section{Model pembelajaran Problem Based Learning} (berbasis masalah) didefinisikan sebagai pembelajaran yang diperoleh melalui proses menuju pemahaman akan resolusi suatu masalah dimana fokusnya adalah pada pembelajaran siswa dan bukan pada pengajaran guru (Miftahul Huda, 2014:271). Model pembelajaran yang berorientasi pada kerangka kerja teoritik konstruktivisme. Dalam model PBL, fokus pembelajaran ada pada masalah yang dipilih sehingga pebelajar tidak saja mempelajari konsep-konsep yang berhubungan dengan masalah tetapi jiga metode ilmiah untuk memecahkan masalah tersebut (Ngalimun, 2016:119). Strategi pembelajaran dengan Problem Based Learning menawarkan kebebasan siswa dalam proses pembelajaran dimana dalam pembelajaran dengan Problem Based Learning, siswa diharapkan untuk terlibat dalam proses penelitian yang mengharuskannya untuk mengidentifikasi permasalahan mengumpulkan data, dan menggunakan data tersebut untuk pemecahan masalah (Rusmono, 2012:74).

Dari beberapa pendapat ahli di atas dapat disimpulkan bahwa model pembelajaran Problem Based Learning adalah suatu pembelajaran yang diperoleh melalui proses belajar dimana guna untuk pemahaman siswa dan untuk memecahkan suatu masalah pada suatu materi yang diberikan guru serta pada proses pembelajaran Problem Based Learning menawarkan kebebasan siswa dalam proses pembelajarandi dalam kelas.

Definisi geografi adalah ilmu realistik. Hal itu ditunjang dengan karakter ilmu yang mengutamakan pemahaman objektif terhadap fenomena geosfer (Momon Sudarman, 2015:29). Berdasarkan pendapat ahli tersebut dapat disimpulkan bahwa geografi tidak hanya terbtas sebagai deskripsi tentang bumi atau permukaan bumi, melainkan meliputi juga analisis hubungan antara aspek fisik dengan aspek manusia. Dengan demikian, perhatian dana analisis pada studi geografi tidak hanya ditunjukkan kepada alam lingkungan, melainkan juga berkenaan dengan manusia serta hubungan di antara keduanya, sekaligus mengkaji faktor alam dan faktor manusia dan keruangan wilayah yang bersangkutan.

Fungsi mata pelajaran geografi adalah sebagai berikut:

a) Mengembangkan pengetahuan tentang polapola keruangan dan proses yang berkaitan.

b) Mengembangkan keterampilan dasar dalam memperoleh data dan informasi, mengomunikasikan, serta menerapkan pengetaahuan geografi untuk kepentingan pembangunan.

c) Menumbuhkan kesadaran dan kepedulian terhadap lingkungan hidup dan sumber daya 
serta toleransi terhadap keragaman sosialbudaya masyarakat (Wardiyatmoko, 2016:5).

Tujuan pembelajaran geografi adalah:

a) Memahami pola spasial, lingkungan, dan kewilayahan seerta proses yang berkaitan dengan gejala geosfera dalam konteks nasional dan global.

b) Menguasai keterampilan dasar dalam memperoleh data dan informasi, mengkomunikasikan, dan menerapkan pengetahuan geografi dalam kehidupan seharihari sebagai warga dunia untuk kepentingan kemajuan bangsa indonesia.

c) Menampilkan perilaku peduli terhadap lingkungan hidup dan memanfaatkan sumber daya alam secara arif serta memiliki toleransi terhadap keragaman budaya bangsa.

d) Menampilkan perilaku cinta tanah air, bangsa sebagai bangsa Indonesia, dan bertanggung jawab terhadap keutuhan Negara Kesatuan Republik Indonesia yang berlandaskan pada Pancasila dan UUD 1945 (Momon Sudarman, 2015:65).

\section{METODOLOGI PENELITIAN}

Metode yang digunakan dalam penelitian adalah metode kuantitatif dengan pendekatan eksperimen. Metode penelitian eksperimen dapat diartikan sebagai metode penilitian yang digunakan untuk mencari pengaruh perlakuan tertentu terhadap yang lain dalam kondisi terkendalikan (Sugiyono, 2015:107).

Dalam penelitian ini menggunakan dua kelas yaitu kelas eksperimen 30 siswa dan kelas kontrol 30 siswa. Penelitian pada kelas eksperimen dan kelas kontrol masing-masing sebanyak 3 kali pertemuan. Kelas eksperimen diberi perlakuan dengan menerapkan metode Reliabilitas dalam kegiatan pembelajaran sedangkan kelas kontrol tidak. Pada kelas kontrol digunakan metode pembelajaran konvensional yang biasa digunakan oleh sekolah.

Metode dokumentasi yaitu mencari data mengenai hal-hal atau variabel yang berupa catatan, transkip, buku, surat kabar, majalah, prasasti, notulen rapat, lengger, agenda dan sebagainya (Arikunto, 2013:274).
Teknik tes adalah serentetan pertanyaan atau latihan serta alat lain yang digunakan untuk mengukur keterampilan, pengetahuan intelegensi, kemampuan atau bakat yang dimiliki oleh individu atau kelompok (Ibid, 193). Tes ini diberikan setelah proses pembelajaran, untuk mengetahui sejauh mana pemahaman siswa tentang materi. Dalam penelitian ini teknik pengumpulan data berupa tes yaitu tes uraian. Yang dilakukan dengan memberikan dua kali pertemuan kepada siswa sebagai bahan perbandingan dari hasil menggunakan model Pembelajaran Problem Based Learning dan tidak menggunakan model Pembelajaran Problem Based Learning.

Untuk mendapatkan instrumen penelitian yang baik, maka perlu dilakukan uji coba instrumen. Instrumen yang baik harus memenuhi dua persyaratan penting yaitu valid dan reliabel (Ibid, 211). Teknik Analisis Data yang digunankan antara lain : 1) Deskripsi data meliputi mean, median, dan modus. 2) Uji persyaratan analisis meliputi uji normalitas dan uji homogenitas. 3) Pengujian hipotesis untuk mengetahui hasil belajar kemampuan berpikir dengan menggunakan uji-t.

\section{HASIL DAN PEMBAHASAN}

Dari hasil penelitian yang dilakukan peneliti yaitu dengan cara memberikan tes diakhir pembelajaran. Hasil kemampuan berpikir analitis siswa pada kelas eksperimen yaitu dengan menggunakan model pembelajaran Problem Based Learning lebih besar dibandingkan hasil kemampuan berpikir analitis siswa yang menggunakan model pembelaajaran konvensional.

Salah satu penyebab nilai hasil belajar siswa pada kelas eksperimen lebih baik adalah adanya kerjasama yang baik oleh anggota kelompok. Semua anggota kelompok memiliki tanggung jawab, pendapat, solusi serta wawasan yang disampaikan oleh setiap anggota kelompok. Pengaruh positif model pembelajaran Problem Based Learning terhadap kemampuan berpikir analitis siswa ini dikarenakan model pembelajaran ini menjadikan siswa lebih mudah memahami materi pembelajaran karenaa dalam proses belajarnya siswa mendapatkan konsep-konsep 
materi pembelajaran secara bermakna dan termotivasi untuk memahami materi.

Berdasarkan pengujian hipotesis dengan menggunakan rumus uji-t, bahwa diketahui pengaruh model pembelajaran Problem Based Learning diperoleh $f_{\text {hitung }}=0,268$. Hal ini berarti model pembelajaran Problem Based Learning memiliki pengaruh positif terhadap kemampuan berpikir analitis siswa karena nilai ini menunjukan angka positif, dan pengaruh tersebut memiliki taraf nyata signifikan 0,05 yang berarti bahwa hubungan adalah signifikan (nyata) $\mathrm{dk}=\mathrm{n}_{1}+\mathrm{n}_{2}-2=30+30$ $-2=58$ ada $\mathrm{t}_{\text {tabel }}=\mathrm{t}_{\text {tabel }}=1,69$ dari hasil perhitungan yang didapat dari $t_{\text {hitung }}>t_{\text {tabel }}$ atau $t_{\text {tabel }}$ $\left\langle\mathrm{t}_{\text {hitung }}=1,69\left\langle 20,01\right.\right.$ atau $\left.\mathrm{t}_{\text {hitung }}>\mathrm{t}_{\text {tabel }}=20,01\right\rangle$ 1,69 maka $\mathrm{H}_{0}$ ditolak dan Ha diterima bahwa dapat disimpulkan bahwa terdapat pengaruh yang signifikan terhadap kemampuan berpikir anaalitis siswa dengan menggunakan model pembelajaran Problem Based Learning.

Hasil penelitian yang diperoleh pada penelitian ini hampir sama dengan penelitian yang telah dilakukan oleh Nur Wahyuni dengan judul pengaruh model pembelajaran Problem Based Learning (PBL) terhadap kemampuan analisis siswa pokok bahasan pencemaran lingkungan kelas $X$ di SMA Negeri Takalar, dengan hasil penelitian yang berupa peningkatan kemaampuan analisis siswa yang diajarkan dengan menggunakan model Problem Based Learning secara signifikan lebih tinggi dari pada siswa yang hanya diajarkan dengan model pembelajaran konvensional. Hal ini dapat dilihat dari hasil rata-rata gain score dimana ratarata pada kelas eksperimen sebesar 82,83, sedangkan pada kelas kontrol memiliki rata-rata gain score sebesar 68,40 (Nur Wahyuni, 2017:).

Berdasarkan kenyataan tersebut dapat disimpulkan bahwa siswa yang belajar dengan menggunakan model pembelajaran Problem Based Learning lebih baik dari pada siswa yang tidak diajarkan dengan menggunakan model pembelajaran Problem Based Learning.

\section{SIMPULAN}

Berdasarkan hasil analisis data mengenai pengaruh model Problem Based Learning terhadap kemampuan berpikir analitis siswa SMA Negeri 2
Banyuasin 1 tahun ajaran 2018/2019, maka dapat disimpulkan bahwa:

a. Melalui penelitian ini maka dapat dilihat hasil belajar siswa dalam penerapan model pembelajaran Problem Based Learning pada mata pelajaran geografi yaitu setelah dilakukan tes akhir dimana nilai hasil tes akhir kelas eksperimen lebih tinggi dibandingkan nilai tes akhir kelas kontrol.

b. Terdapat atau ada pengaruh model pembelajaran Problem Based Learning terhadap kemampuan berpikir analitis siswa. Hasil belajar siswa menggunakan model pembelajaran Problem Based Learning pada kelas eksperimen dengan rata-rata 75,183 , sedangkan pada kelas control dengan pembelajaran konvensional memiliki rata-rata 64,5 .

\section{DAFTAR PUSTAKA}

Arikunto, Suharsimi. (2013). Prosedur Penelitian. Jakarta: Rineka Cipta.

Daryanto dan Tasrial. (2012). Konsep Pembelajaran Kreatif. Yogyakarta:Gava Media.

Huda, Miftahul. (2014). Model-Model Pengajaran dan Pembelajaran. Yogyakarta: Pustaka Pelajar.

Majid, Abdul. (2009). Perencanaan Pembelajaran. Bandung: PT Remaja Rosdakarya.

Ngalimun. (2016). Strategi dan Model Pembelajaran. Sleman Yogyakarta: Aswaja Pressindo.

Rusman. (2012). Model-Model Pembelajaran Mengembangkan Profesional Guru. Jakarta: Rajawali pers.

Rusmono.(2012). Strategi Pembelajaran dengan

Problem Based Learning itu

perlu. Ciawi Bogor: Ghalia Indonesia.

Suyadi. (2015). Strategi Pembelajaran Pendidikan Karakter. Bandung: Rosdakarya.

Sudarma, Momon. (2015). Model-Model Pembelajaran Geografi. Yogyakarta: Ombak.

Sugiyono. (2015). Metode Penelitian Pendidikan pendekatan Kuantitatif, Kualitatif, dan R\&D. Bandung: Alfabeta. 
Wardiyatmoko. (2016). Geografi untuk SMA/MA kelas XI. Jakarta Utara: Erlangga.

Wena, Made. (2009). Strategi Pembelajaran inovatif Kontemporer. Jakarta: Bumi Aksara.
Wahyuni, Nur. (2017). "Pengaruh Model Pembelajaran Problem Based Learning terhadap kemampuan analisis siswa pokok bahasan pencemaran lingkungan kelas $X d i$ SMAN 1 Takalar". Jurnal (diterbitkan). Makasar: Universitas Islam Negeri (UIN) Allaudin Makasar. 